\title{
Global Capitalism and Critical Awareness of Language
}

\section{Norman Fairclough}

Department of Linguistics and Modern English Language, Lancaster University, LA 1 4SE

As the shape of the new global social order becomes clearer, so too does the need for a critical awareness of language as part of language education. I discuss, with a focus on discourse, several key features of late modern society which help make the case for critical awareness of discourse: the relationship between discourse, knowledge and social change in our 'information' or 'knowledge-based' society; what Smith (1990) has called the 'textually-mediated' nature of contemporary social life; the relationship between discourse and social difference; the commodification of discourse; discourse and democracy. I then draw these together by tying the case for CLA to the nature of the new global capitalism, and conclude the paper with discussions of how CLA is anchored in 'critical discourse analysis' (and, through that, in critical social science generally), and of how the question of CLA is framed within the wider question of the nature and purposes of education.

It is over 10 years since an initial paper on critical language awareness (CLA) was given at the British Association for Applied Linguistics annual conference (later published in Clark et al., 1990, 1991, see also Ivanič, 1990; Fairclough, 1992). The work on CLA was based upon the conviction that because of contemporary changes affecting the role of language in social life, a critical awareness of language is 'a prerequisite for effective democratic citizenship, and should therefore be seen as an entitlement for citizens, especially children developing toward citizenship in the educational system' (Fairclough, 1992:2-3). We argued that CLA should be a basic concern in language education. Has the case for this weakened or strengthened in the intervening years? I want argue that as the shape of the new global social order becomes clearer, so too does the need for a critical awareness of language as part of people's resources for living in new ways in new circumstances. Our educational practices have some way to go before they begin to match up to our educational needs. At the same time, although I continue using the expression 'critical language awareness' because it is relatively well-known, it has also become clearer that what is at issue is a critical awareness of discourse which includes other forms of semiosis as well as language: visual images in particular are an increasingly important feature of contemporary discourse (Kress \& van Leeuwen, 1996).

\section{An Example: The Discourse of 'Flexibility'}

I shall begin with an example which points to a number of features of social life in contemporary ('late modern') society which demand a critical awareness of discourse. Most accounts of change in contemporary social life give a more or less central place to change in the economic system: the change from 'Fordism' to 'flexible accumulation', as Harvey (1990) puts it. Fordism is the 'mass 
production' form of capitalism (named after the car magnate Henry Ford) which dominated the earlier part of this century. Flexible accumulation is a more complex concept but it basically means greater flexibility at various levels - in production (the production process can be quickly shifted to produce small batches of different products), in the workforce (part-time and short-term working, extensive reskilling of workers), in the circulation of finance, and so forth. Harvey points out that some academic analysts see 'flexibility' as no more than a new discourse which is ideologically motivated - if working people can be persuaded that 'flexibility' is an unavoidable feature of contemporary economies, they are more likely to be 'flexible' about their jobs disappearing, the need to retrain, deteriorating pay and conditions of work, and so forth. Harvey disagrees. Flexibility is a real feature of contemporary economies for which there is ample scientific evidence - though that does not mean that 'flexible accumulation' has totally displaced 'Fordism', the reality is rather a mix of old and new regimes. Nor does it mean that the discourse of flexibility is irrelevant to the reality of flexible accumulation. Far from it: the discourse is an irreducible part of the reality. The change from Fordism to flexible accumulation is inconceivable without the change in economic discourse. Why? Because the emerging global economy is the site of a struggle between the old and the new, and the discourse of flexibility is a vital symbolic weapon in that struggle. It is as Bourdieu (1998) has put it a 'strong discourse', that is a discourse which is backed by the strength of all the economic and social forces (the banks, the multinational companies, politicians, and so on) who are trying to make flexibility - the new global capitalism - even more of a reality than it already is. Neoliberal discourse contributes its own particular, symbolic, form of strength to the strength of these social forces.

Let me briefly clarify my example. My focus is on the metaphor of 'flexibility' which is at the centre of the economic discourse of 'flexible accumulation' for which Harvey (1990:47-97) gives an analytical account — including, for example, its construction of the labour market in terms of 'core' and 'periphery' employees. Elements of this discourse, and especially the metaphor of flexibility itself, are widely distributed within many types of non-economic discourse (examples shortly). The discourse of flexible accumulation enters complex and shifting configurations with other discourses within a field I am calling 'neoliberal discourse' - for instance with a management discourse which centres on the 'mission statement' which Swales and Rogers (1995) have described. This is a complex and unstable area which needs detailed research.

One accessible place to find the discourse of flexibility used within this struggle over global economy is in the books written by management 'gurus' which seem to dominate airport and railway station bookshops (for example Peters, 1994). But it is a discourse that turns up in many other contexts. One of them is politics - New Labour's 'Third Way', for instance, can be summed up as follows: economic flexibility (on the model of the World Bank and the IMF) is inevitable, but government must strive to include those it socially excludes. Here is Blair in his first major speech after becoming Prime Minister:

We must never forget that a strong, competitive, flexible economy is the prerequisite for creating jobs and opportunities. But equally we must never 
forget that it is not enough. The economy can grow while leaving behind a workless class whose members become so detached that they are no longer full citizens. (Blair, 1997)

But the discourse of flexibility also penetrates into everyday language. Here for instance is an extract from an ethnographic interview with 'Stephen' from Cleveland in North-East England who does 'fiddly jobs', i.e. works illegally in the black economy while claiming social benefits. He is talking about the work he does:

It's a matter of us being cheaper. It's definitely easier than having a lot of lads taken on permanently. It would cost them more to put them on the books or pay them off. It's just the flexibility. You're just there for when the jobs come up, and he [the 'hirer and firer'] will come and get you when you're needed. You need to be on the dole to be able to do that. Otherwise you'd be sitting there for half the year with no work and no money at all. (Quoted in MacDonald, 1994: 515)

We might pessimistically think of everyday language as colonised by this discourse of the powerful, and that is no doubt partly true, but here is 'Stephen' appropriating the discourse in constructing his own perfectly coherent rationale for his (illegal) way of living. One aspect of economic flexibility from his perspective is that companies need the flexibility of workers doing fiddly jobs.

Like other prominent discourses, the discourse of flexibility draws some comment and critique - a critical awareness of language is not wholly something which has to be brought to people from outside, it arises within the normal ways people reflect on their lives as part of their lives. But this ordinary form of critique has its limits. People need to know about discourses like this - for instance, what insights it gives us into the way economies work or could work, and what other insights it cuts us off from; whose discourse it is, and what they gain from its use; what other discourses there are around, and how this one has become so dominant. People practically need to know such things, because not knowing them makes it harder for them to manage in various parts of their lives: as trade unionists - whether resisting shifts to part-time and short-time work is fighting the inevitable; as managers - what strengths and limitations the metaphor of flexibility has for their organisations; as citizens - whether there is a 'Third Way'; as parents - what sort of world to prepare their children for. But such knowledge about discourse has to come from outside, from theory and research, via education.

I want to proceed by discussing, with a focus on discourse, several key features of late modern society which this example touches on, and which I think help make the case for critical awareness of discourse. Actually the earlier ones arise more easily from the example of the discourse of flexibility than the later ones. I discuss these features of late modernity under the following headings: the relationship between discourse, knowledge and social change in our 'information' or 'knowledge-based' society; what Smith (1990) has called the 'textually-mediated' nature of contemporary social life; the relationship between discourse and social difference; the commodification of discourse; discourse and democracy. I shall then draw these together by tying the case for CLA to the 
nature of the new global capitalism, and conclude the paper with discussions of how CLA is anchored in 'critical discourse analysis' (and, through that, in critical social science generally), critical discourse awareness and critical pedagogy.

\section{Discourse, knowledge and social change}

The example points to a relationship between change in economic discourse, new economic knowledge, and change in economic practices. As I stated earlier, it is a matter of discourse, not just language - knowledges are increasingly constituted in multisemiotic ways in contemporary society (Kress \& van Leeuwen, 1996; New London Group, 1996). Information- or knowledge-based late modern societies are characterised, as Giddens has put it, by enhanced reflexivity - we are constantly reshaping our social practices on the basis of knowledge about those practices. This is true in the domain of work but also, for instance, in how people conduct their personal relationships - the media are full of expert advice. On one level, reflexivity is an inherent property of all social practices - any social practice includes the constructions of that practice produced by its practitioners as part of the practice. What is different about late modernity is the ways in which 'expert systems' (such as the sciences and social sciences) are systematically integrated into reflexive processes (Giddens, 1991). These expert systems can be thought of as evaluating existing knowledges in the practical domain in focus (for example the economy) and producing new knowledges. Since knowledges are constituted as discourses, particular ways of using language, this means that they are in the business of evaluating and changing discourses. Evaluating discourses means setting them against shifting understandings of what material possibilities there are in the practical domain concerned (for example the economy), which are, in turn, instantiated within new discourses. In such practical contexts, discourses are evaluated not in terms of some impossible 'absolute truth', but in terms of 'epistemic gain' — whether they yield knowledges which allow people to improve the way in which they manage thier lives.

The business of evaluating and changing knowledges and discourses is something which an increasing number of people are involved in as part of the work they do. It is a major concern of educational institutions to teach them how to do this, and part of the current preoccupation with 'learning to learn', and other thematisations of 'learning' in contemporary education and business - 'the learning society', businesses as 'learning organisations', 'lifelong learning' — see, for example, the Dearing Report on universities Higher Education in the Learning Society (National Committee of Inquiry into Higher Education, 1997). What I want to argue is that the resources for learning and for working in a knowledge-based economy include a critical awareness of discourse - an awareness of how discourse figures within social practices, an awareness that any knowledge of a domain of social life is constituted as one discourse from among a number of co-existing or conceivable discourses, that different discourses are associated with different perspectives on the domain concerned and different interests, an awareness of how discourses can work ideologically in social relations of power, and so forth. It is on the basis of such understandings of how discourse works within social practices that people can come to question 
and look beyond existing discourses, or existing relations of dominance and marginalisation between discourses, and so advance knowledge. If on the other hand language and other semiotic modalities are viewed as simply transparent media for reflecting what is, the development of knowledge is likely to be impeded.

\section{Textually-mediated Social Life}

The presence of the discourse of flexibility in Stephen's talk is an illustration of the textual mediation of social life: in contemporary societies, the discourses/knowledges generated by expert systems enter our everyday lives and shape the way we live them. Contemporary societies are knowledge-based not only in their economies but even, for instance, in the ways in which people conduct their personal relationships. Expert knowledges/discourses come to us via texts of various sorts which mediate our social lives - books, magazines, radio and television programmes, and so forth. These processes of textual mediation bind together people who are scattered across societies into social systems - one of Smith's examples is how textually mediated constructions of femininity lock women scattered across social space into the economic system of commodity production and consumption, in that femininity is constructed in terms of the purchase and use of commodities such as clothes (Smith, 1990). Moreover, the distances in space and time across which these processes of textual mediation operate are increasing. Modernity can be seen as a process of 'time/space compression', the overcoming of spatial and temporal distance, and late modernity is marked by a twist in that process which is widely referred to as 'globalisation' (Harvey, 1990; Giddens, 1991). The vehicles for this spatio-temporally extended textual mediation are the new media — radio, television, and information technology.

As everyday lives become more pervasively textually mediated, people's lives are increasingly shaped by representations which are produced elsewhere. Representations of the world they live in, the activities they are involved in, their relationships with each other, and even who they are and how they (should) see themselves. The politics of representation becomes increasingly important whose representations are these, who gains what from them, what social relations do they draw people into, what are their ideological effects, and what alternative representations are there? The example of Stephen's talk is a case in point. His representation of his own life in the black economy draws upon the discourse of flexibility. We might question whether his construction of his own life and identity has been ideologically invested, drawn into the social relations between the powerful groups who control economies and back neoliberalism and the rest of us. However, the picture is more complex and more hopeful. As I suggested earlier, his talk does not simply reproduce the discourse of flexibility, it works it in a particular - and ironic - way into a rationale for his own way of living based on a perfectly coherent, if non-standard, view of the new capitalism - part of the flexibility that companies need is the flexibility of illegal black labour. The example shows that people are not simply colonised by such discourses, they also appropriate them and work them in particular ways. Textually mediated social life cuts both ways - it opens up unprecedented resources for people to 
shape their lives in new ways drawing upon knowledges, perspectives and discourses which are generated all over the world. But in so doing it opens up new areas of their lives to the play of power. There is a colonisation-appropriation dialectic at work. Whether on balance people gain or lose depends on where they are positioned in social life - the fact that new possibilities are opened up does not mean people are unconditionally free to take them. But my main point is this: if people are to live in this complex world rather than just be carried along by it, they need resources to examine their placing within this dialectic between the global and the local - and those resources include a critical awareness of language and discourse which can only come through language education.

\section{Discourse, Social Difference and Social Identity}

Discourses are partial and positioned, and social difference is manifest in the diversity of discourses within particular social practices. Neoliberal economic discourse, for instance, is only one of many economic discourses and, as I have indicated earlier, it corresponds to a specific perspective and set of interests. Critical awareness in this case is a matter of seeing the diversity of discourses and their positioned nature.

But there are other aspects of social difference. Late modern societies are increasingly socially diverse societies, not only in that migration has led to greater ethnic and cultural diversity, but also because various lines of difference which were until recently relatively covered over have become more salient differences of gender and sexual orientation, for example. Differences are partly semiotic in nature - different languages, different social dialects, different communicative styles, different voices, different discourses. The predominant ethos, for instance, in European societies is that differences which have in the past been suppressed should now be recognised. But since people need to work together across difference, differences have to be negotiated. People need to work across differences in work, politics, cultural activities and everyday life. But it is increasingly understood that social difference is not only difference between people but also difference within people. Indeed, recognising the difference within is the basis for being open to a non-suppressive negotiation of differences between people and groups (Barat, 1998). Working across differences is a process in our individual lives, within the groups we belong to, as well as between groups. Working across differences entails semiotic hybridity - the emergence of new combinations of languages, social dialects, voices, genres and discourses. Hybridity, heterogeneity, intertextuality are salient features of contemporary discourse also because the boundaries between domains and practices are in many cases fluid and open in a context of rapid and intense social change - the negotiation of social difference includes, for instance, the negotiation of differences between educators, advertisers and business managers, and between students and consumers of commodities, within educational institutions which are increasingly forced into operating in market ways. But negotiating differences is simultaneously negotiating identities - working out how I or we relate to others is simultaneously working out who I am or who we are. The radical disarticulations and rearticulations of contemporary social life radically unsettle social identities, and the search for and construction of identities is a constant 
process and a major preoccupation, but it should be framed in terms of the problem of learning to live with difference (New London Group, 1996). Once again, people need from education a range of resources for living within socially and culturally diverse societies and avoiding their dangers, including chauvinism and racism. A critical awareness of discourse is part of what is needed.

\section{Commodification of Discourse}

There is still a link, if a more tenuous one, between my next theme and the example of the discourse of flexibility. I referred earlier to the books of management gurus which fill airport bookstalls and are filled with neo-liberal economic discourse. These books are about big business, but they are also big business themselves. They are generally rather successful commodities, as one can see from the impressive sales figures which are often emblazoned on their covers. The stuff these commodities are made of is, of course, paper, ink and so forth, but it is also language and other sorts of semiotic stuff. They are worked up into commodities, carefully designed to sell. Semiotic stuff is a feature of a great many commodities these days - the nature of commodities has been changing, with a shift in emphasis broadly from goods that are more physical than cultural (like cars) to goods that are more cultural than physical (like books, or television programmes, or advertisements). Many goods now are services, like what you pay for in a smart restaurant which is not just the food but the ambiance, which includes the appearance, behaviour and talk of the staff - language is part of the service, part of the goods. As commodities become semioticised, discourse becomes commodified (Lyotard, 1986-7) — it becomes open to processes of economic calculation, it comes to be designed for success on markets. For instance, service industries are full of forms of ostensibly ordinary talk which are designed to seem ordinary, to mobilise all the selling power of ordinariness in a society which values it even in institutional and organisational contexts.

The commodification of discourse could be seen as part of a more general application of instrumental or 'means-end' rationality to discourse which also takes the form of government and other organisations making discourse more bureaucratic. I have referred to this elsewhere as 'technologisation of discourse' (Fairclough, 1996) - instrumental rationality applied in the shaping and reshaping of discursive practices (such as interviews) within more general processes of engineering institutional cultures to enhance their 'performativity' (Lyotard, 1984). Technologisation of discourse produces general formulas for change which tend to ignore differences of context, so that one effect of such cultural technologisation is normalisation, homogenisation and the reduction of difference - for instance the imposition of a standardised audit culture and the discourse that goes with it (the discourse of 'quality control') throughout the public domain, including education. This process rests upon a critical awareness of discourse, but it also calls for a critical awareness of discourse amongst those who are on the receiving end of it, people who work in commercial, governmental and public service organisations in a variety of capacities.

\section{Discourse and Democracy}

The discourse of flexibility is predominant within the political systems of, for 
instance, Great Britain and the USA - all of the major parties use it and take it for granted. It is part of a widely observed narrowing down of the political spectrum - parties are becoming increasingly similar in their policies, and the differences between them are increasingly differences of style. One aspect of this process is what Marcuse identified 30 years ago as the closing down of the universe of discourse' (Marcuse, 1964) - the predominance of a single economic-political discourse across the political spectrum.

We might see the narrowing of political discourse as a symptom of the political system becoming cut off from the sources of political diversity and change in social life. This has been widely debated in recent years as a crisis of the 'public sphere' (Habermas, 1989; Calhoun, 1992), troubles to do with the apparent absence of effective spaces and practices where people as citizens can deliberate over issues of common social and political concern, and their deliberations can shape the policy decisions that are made. The broadcast media are full of dialogue on such issues, but it is a dialogue that is deeply flawed in terms of its public sphere credentials - in terms of who has access to it, in terms of what gets onto its agendas, in terms of who controls its flow, and in terms of it being designed to maximise audience and entertain. The task of reconstructing the public sphere is at the heart of the defence and enhancement of democracy. It is already being undertaken within social movements which are active outside the official political system. But it is also a task for educational institutions including schools and universities, whose standing as public spheres has been undermined by recent institutional changes (Giroux, 1997). One way forward here is suggested by Billig (1991): that we conceive of teaching people to think as teaching people to argue, and put our energies into making educational institutions as open as possible as spaces for argument. Negotiating across difference is again a central concern for the contemporary public sphere - political dialogue in socioculturally diverse societies has to be oriented to alliances around particular sets of issues. In this case, a critical awareness of discourse is essential for the work of experimentation and design which is necessary to find effective forms of dialogue which facilitate open argumentation and forms of action in common which do not suppress difference (Fairclough, 1998).

\section{Critical Awareness of Discourse and the New Global Capitalism}

I began from the example of neo-liberal economic discourse. The choice of example was not incidental, because it is the new global capitalism which this discourse simultaneously represents and constitutes that makes critical awareness of discourse an increasingly necessary resource for people. The new global capitalism opens up new possibilities for people yet at the same time creates new problems. A critical awareness of discourse is necessary for both - on the one hand, for opening up new knowledges in the knowledge-based economy, and for exploring new possibilities for social relationships and identities in socially diverse communities; on the other hand, for resisting the incursions of the interests and rationalities of economic, governmental and other organisational systems into everyday life - such as the commodification of the language of everyday life, the colonising incursions of textually mediated representations and the threat of global capitalism to democracy, for example, in the ways it 
manipulates national governments. Late modernity is characterised by increasing reflexivity including language reflexivity, and people need to be equipped both for the increasing knowledge-based design of discursive practices within economic and governmental systems, and for critique and redesign of these designed and often globalised practices as workers, consumers, citizens, members of social and lifestyle groups (for example as women, Blacks, trade unionists, environmental activists, and so forth).

\section{Critique: Social Science, Discourse Analysis, Discourse Awareness}

The need for critical awareness of discourse in contemporary society should make it a central part of language education in schools, colleges and universities. I come to some educational issues later. Such a critical discourse awareness programme would rest upon and recontextualise (Bernstein, 1990) critical research on discourse, which in turn is based in critical traditions in social science. While these are obviously not the focus of this paper, readers may find useful a brief sketch of one view of critical discourse analysis and critical social science, starting with the latter.

Social life can be seen as constituted by networks of social practices, each of which consists of various elements including discourse (as well as material activities, institutional rituals, social relations, beliefs and values) articulated together in a dialectical relationship, such that each element internalises all others without being reducible to them - each element has its own distinctive logic and generative power (Collier, 1994; Chouliaraki \& Fairclough, forthcoming; Harvey, 1996). A critical social science explicates both structural relations between and within social practices within such networks, and the dialectical tension between structure and event which makes structures both preconditions for events and (transformed) outcomes of them (Chouliaraki \& Fairclough, forthcoming; Bourdieu \& Wacquant, 1992). One view of critique is the concept of 'explanatory critique' associated with 'critical realism' (Bhaskar, 1986; Collier, 1994): critique involves four stages - identification of a problem, identification of what it is in the network of social practices that gives rise to the problem, consideration of whether and how the problem is functional in sustaining the system (for example whether it works ideologically), and identification of real possibilities within the domain of social life in question for overcoming the problem. What constitutes a problem can only be established through dialogue between those involved often not an easy process, or one that yields clear answers.

Critical research on discourse has been carried out under the names of 'critical discourse analysis' and 'critical linguistics' (Fairclough \& Wodak, 1997). Critical discourse analysis aims to provide a framework for systematically linking properties of discoursal interactions and texts with features of their social and cultural circumstances. The network of social practices is described from a specifically discoursal perspective as an 'order of discourse' consisting of discourses and genres in particular relationships with each other, but with an orientation to shifts in boundaries within and between orders of discourse as part of social and cultural change. Particular discursive events and longer-term series of events tied to specific social conjunctures are described in terms of the potentially innovative ways in which they draw upon the orders of discourse 
which condition them - it is that relationship to orders of discourse that mediates the connection between detailed semiotic/linguistic features of texts and interactions, and social and cultural structures and processes. Problems of two sorts are in focus: needs-based problems - discursive practices which in some way go against people's needs (for example, forms of doctor-patient communication which do not allow patients to recount what they see as all the relevant aspects of their health problems); and problems with representations (for example constructions of social groups such as women or cultural minorities which have detrimental social consequences for them).

Critical discourse awareness programmes will be concerned to recontextualise this body of research in ways which transform it, perhaps quite radically, into a practically useful form for educational purposes, including a metalanguage.

\section{Critical Discourse Awareness and Education}

Recent educational reforms have sharply raised the question of what education is for, and for whom. The dominant view of education - evident, for instance, in the recent Dearing Report Higher Education in the Learning Society (National Committee of Inquiry into Higher Education, 1997) - sees it as a vocationally-oriented transmission of given knowledge and skills. What is perhaps most distinctive about this view of education is its focus upon the teaching and learning of 'key skills' which are seen as transferable from one sphere of life to another, and as the basis for future success including successful 'lifelong learning'. Given that one of these key skills is 'communication' (the others identified in the Dearing report are numeracy, information technology and learning to learn), this view of education rests upon a view of discourse discourse as 'communication skills'.

What is wrong with seeing discourse as communication skills? Let me focus on three problems. First, it is assumed that a communication skill, once learnt, can be freely transferred from one context to another. I think there is an interesting connection between this assumption and the tendencies I have identified as textually-mediated social life and the technologisation of discourse - discursive practices are indeed transferred across contexts in late modern social life. But what this first assumption misses is what I have referred to as the colonisationappropriation dialectic (which is also a global-local dialectic) - even where such transfers take place, it does not mean that we find the same discursive practice in all contexts, for even the most globally dispersed discursive practice is always locally recontextualised, transformed and appropriated. It is inviting disaster to assume that if you have learnt to interview candidates for admission to university, you know how to interview personalities on a television chat show. Second, it is assumed that there is a simple relationship between what is actually said (or more generally done) in the course of some social practice, and skills, internalised models of how to say/do it - that discourse is a mere instantiation of such models (Fairclough, 1988). On the contrary, discourse is a complex matching of models with immediate needs in which what emerges may be radically different from any model, ambivalent between models, or a baffling mixture of models, and where flair and creativity may have more impact than skill. Thirdly, and most seriously, it is assumed that there is a given and accepted 
way of using language to do certain things, as if discourse was a simple matter of technique, whereas any way of using language which gets to be given and accepted does so through applications of power which violently exclude other ways, and any way of using language within any social practice is socially contestable and likely to be contested. From this point of view, any reduction of discourse to skills is complicit with efforts on the part of those who have power to impose social practices they favour by getting people to see them as mere techniques.

In critiquing the view of discourse as communication skills, I am also critiquing the view of education as a transmission of knowledge and skills. For viewing discourse as skills is just one aspect of viewing knowledge and skills in general as determinate, uncontested, and given externally to the learner; and it is only on such assumptions about what is to be taught and learnt that the process can be viewed as 'transmission'. We can broaden out the argument against discourse as skills into a different view of knowledge and skills in education: they are always provisional and indeterminate, contested and, moreover, at issue in social relationships, within which all teachers and learners are positioned. In a critical view of education, knowledge and 'skills' are indeed taught and learnt, but they are also questioned - a central concern is what counts as knowledge or skill (and therefore what does not), for whom, why, and with what beneficial or problematic consequences. In the Dearing Report, higher education promotes knowledge, skills and understanding; my comments here take understanding to mean a questioning of knowledge and skills, and problematise the foregrounding of 'key skills' in the Report.

Perhaps it has always been the case that education has been relatively critical for some, though usually for a small elite. In the new work order (Gee et al., 1996), there is a need for a small elite of symbolic-analytic workers for whom the new system may demand a critical education (including a critical awareness of discourse). The danger is a new form of educational stratification which separates them from those likely to become other categories of workers (routine production workers, and workers in service industries) or to join the 'socially excluded' (including unemployed). That would be in line with the contemporary tendency of the purposes of education to narrow down towards serving the needs of the economy. The alternative is some vision of education for life within which a critical awareness of discourse is necessary for all.

\section{Correspondence}

Any correspondence should be directed to Dr Norman Fairclough, Department of Linguistics and Modern English Language, Lancaster University, Lancaster LA1 4SE, UK (n.fairclough@lancs.ac.uk).

\section{Note}

1. Although pedagogy is not my major concern here, I envisage the sort of four-part pedagogy set out by the New London Group (1996). Its elements are: development of the ability to engage successfully in a range of practices through immersion in authentic Situated Practice; an awareness and understanding of these practices through Overt Instruction; a capacity to critique those practices as socially particular and partial actualities from within a wider range of possibilities through Critical 
Framing; and Transformed Practice, experimentation with new practices reflexively informed by Overt Instruction and especially Critical Framing. What is envisaged, then, is a link between awareness and practice, awareness opening up new possibilities for practice.

\section{References}

Barat, E. (1998) Women's identities: A tension between discourses and experience. Paper delivered at conference on Critical Discourse Analysis, Brasilia, May.

Bernstein, B. (1990) The Structuring of Pedagogic Discourse. London: Routledge.

Bhaskar, R. (1986) Scientific Realism and Human Emancipation. London: Verso.

Billig, M. (1991) Ideology and Opinion. London: Sage.

Blair, Tony (1997) Speech at the Aylesbury Housing Estate, Southwark, 2 June.

Bourdieu, P. (1998) L'essence du neo-liberalisme. Le Monde Diplomatique, March.

Bourdieu, P. and Wacquant, L. (1992) An Invitation to Reflexive Sociology. Cambridge: Polity Press.

Calhoun, C. (1992) Habermas and the Public Sphere. Cambridge, MA: MIT Press.

Chouliaraki, L. and Fairclough, N. (forthcoming) Discourse in Late Modernity. Edinburgh University Press.

Clark, R., Fairclough, N., Ivanič, R. and Martin-Jones, M. (1990) Critical language awareness Part 1: A critical review of three current approaches. Language and Education 4 (4), 249-60.

Clark. R., Fairclough, N., Ivanič, R. and Martin-Jones, M. (1991) Critical language awareness Part 2: Towards critical alternatives. Language and Education 5 (1), 41-54.

Collier, A. (1994) Critical Realism. London: Verso.

Fairclough, N. (1988) Register, power and sociosemantic change. In D. Birch and M. O'Toole (eds) The Functions of Style. London: Pinter Publications.

Fairclough, N. (ed.) (1992) Critical Language Awareness. London: Longman.

Fairclough, N. (1996) Technologisation of discourse. In C. Caldas-Coulthard and M. Coulthard (eds) Texts and Practices: Readings in Critical Discourse Analysis. London: Routledge.

Fairclough, N. (1998) Democracy and the public sphere in critical research on discourse. Paper given at conference on Discourse, Politics and Identity in Europe, Vienna, April.

Fairclough, N. and Wodak, R. (1997) Critical discourse analysis. In T. van Dijk (ed.) Discourse as Social Interaction. London: Sage.

Gee, J., Hull, G. and Lankshear, C. (1996) The New Work Order: Behind the Language of the New Capitalism. London: Allen \& Unwin.

Giddens, A. (1991) Modernity and Self-Identity. Cambridge: Polity Press.

Giroux, H. (1997) Pedagogy and the Politics of Hope. Boulder, CO: Westview Press.

Habermas, J. (1989) Structural Transformation of the Public Sphere. Cambridge, MA: MIT Press.

Harvey, D. (1990) The Condition of Postmodernity. Oxford: Blackwell.

Harvey, D. (1996) Justice, Nature and the Geography of Difference. Oxford: Blackwell.

Ivanič, R. (1990) Critical language awareness in action. In R. Carter (ed.) Knowledge about Language - The LINC Reader. London: Hodder \& Stoughton.

Kress, G. and van Leeuwen, T. (1996) Reading Images: The Grammar of Visual Design. London: Routledge.

Lyotard, J.-F. (1984) The Postmodern Condition. Manchester: University of Manchester Press.

Lyotard, J.-F. (1986/7) Rules and paradoxes and the svelte appendix. Cultural Critique 5, 209-19.

MacDonald, R. (1994) Fiddly jobs, undeclared working and the something for nothing society. Work, Employment and Society 8 (4), 507-30.

Marcuse, H. (1964) One-Dimensional Man. London: Abacus.

National Committee of Inquiry into Higher Education (1997) Higher Education in the Learning Society (The Dearing Report). London: HMSO. 
New London Group (1996) A pedagogy of multiliteracies: Designing social futures. Harvard Educational Review 66 (1), 60-92.

Peters, T. (1994) The Tom Peters Seminar. London: Vintage Books.

Smith, D. (1990) Texts, Facts and Femininity. London: Routledge.

Swales, J. and Rogers, P. (1995) Discourse and the projection of corporate culture: The Mission Statement. Discourse and Society 6 (2), 223-42. 